\title{
O BRASIL E A CRISE FINANCEIRA GLOBAL: AVALIANDO OS CANAIS DE TRANSMISSÃO NAS CONTAS EXTERNAS*
}

\author{
Daniela Magalhães Prates ${ }^{*}$ \\ André Moreira Cunha ${ }^{\star * *}$ \\ Marcos Tadeu Caputi Lélis ${ }^{\star * * *}$
}

\begin{abstract}
RESUMO Este trabalho analisa alguns dos impactos da crise financeira global em curso sobre as contas externas do Brasil. Seus mecanismos de transmissão, comerciais e financeiros, são examinados de forma detalhada, de modo a avaliar a potencial emergência de novas vulnerabilidades. Argumenta-se que o desempenho das contas externas depende da interação entre fatores exógenos, que têm sido predominantes, $\mathrm{e}$ a características estruturais da economia. Conclui-se com recomendações de política econômica.
\end{abstract}

PALAVRAS-CHAVE: crise financeira global; comércio e finanças; Brasil

\section{BRASIL AND THE GLOBAL FINANCIAL CRISIS: ASSESSING THE TRASMISSION CHANNELS IN THE EXTERNAL ACCOUNTS}

ABSTRACT In this paper we analyze some impacts of the current global financial crisis on Brazilian external accounts. Financial and trade transmission mechanisms are examined in detail in order to access new potential external vulnerabilities. We argue

*Artigo enviado em 17 de setembro de 2010 e aprovado em 3 de maio de 2011.

** Professora-doutora do Instituto de Economia da Unicamp e pesquisadora do Centro de Conjuntura e Política Econômica deste Instituto (Cecon-IE). Pesquisadora do CNPq. E-mail: daniprates@eco.unicamp.br.

*** Professor do Departamento de Ciências Econômicas da Universidade Federal do Rio Grande do Sul (UFRGS) e Pesquisador do CNPq. E-mail: andre.cunha@ufrgs.br.

**** Coordenador da área de Inteligência Comercial e Competitiva da APEX-Brasil. E-mail: marcos. lelis@apexbrasil.com.br. 
that external accounts performance depends on the interaction between external factors, which have been more relevant, and structural characteristics of the economy. We conclude with policy recommendations.

KEY WORDS: global financial crisis; trade and finance; Brazil

JEL CLASSIFICATION: F32; F42. 


\section{INTRODUÇÃO}

O último trimestre de 2008 marcou o agravamento da crise financeira originada no mercado de hipotecas de alto risco (subprime) dos EUA. Seu caráter passou a ser global, afetando virtualmente todas as classes de ativos financeiros e comprometendo sensivelmente o desempenho do comércio internacional e das economias avançadas e emergentes. Embora o ano de 2009 tenha sido marcado pela pior contração da economia mundial do pós-guerra, parece haver uma ampla convergência de percepções de que os mega-pacotes de socorro financeiros e as medidas fiscais contra-cíclicas evitaram a reprodução de uma quadro depressivo à la 1929 (EICHENGREEN, 2009). Aos poucos uma parcela importante da economia mundial, especialmente entre os países emergentes, vai retomando os níveis de atividade pré-crise. Todavia, passados dois anos daquele momento de maior gravidade, os analistas se dividem entre os sugerem que o pior já passou e os que vislumbram um cenário de maior instabilidade nos mercados financeiros e de recuperação mais lenta no tecido produtivo dos países mais gravemente atingidos pela crise. O agravamento da situação fiscal na Europa parece reforçar a percepção da importância de se ter cautela diante de diagnósticos mais otimistas quanto aos desdobramentos da conjuntura recente (IMF, 2010; IIF, 2010).

Este artigo procura avaliar os impactos da crise financeira global sobre as contas externas brasileiras ${ }^{1}$. O Brasil revelou uma capacidade inédita de resistência às turbulências externas, experimentando uma retração modesta em sua renda no ano de 2009, com sinais claros de plena recuperação (e superação) dos patamares pré-crise de desempenho no primeiro semestre de 2010. Todavia, na perspectiva aqui sugeri$\mathrm{da}$, essa crise teve efeitos negativos importantes no balanço de pagamentos do país, evidenciando vulnerabilidades que poderão se agravar nesta etapa de recuperação. Atenção especial será dada a dois aspectos:

i) a mudança na composição dos passivos externos, com o aumento dos estoques de capital (sobretudo de portfólio) vis-à-vis os de dívida;

ii) a tendência de forte deterioração dos saldos comerciais.

A crise em curso afirmou, uma vez mais, que as condições da economia internacional determinam o padrão das contas externas, especialmente no caso dos países

\footnotetext{
${ }^{1}$ Já há uma importante literatura produzida no Brasil sobre os impactos da crise financeira global sobre a economia do país. Sem a pretensão de se fazer uma revisão exaustiva, sugere-se a leitura dos trabalhos organizados por Bacha e Goldfajn (2009), Giambiagi e Barro (2009), Velloso (2009) e Bresser-Pereira (2010a, 2010b). Sobre os impactos sobre o comércio exterior brasileiro, ver: Castilho (2011).
} 
periféricos ${ }^{2}$, como o Brasil. A evolução das contas externas brasileiras após a adoção do regime de câmbio flutuante foi condicionada por fatores macroeconômicos (regimes cambial e monetário) e estruturais (grau de abertura financeira e comercial), mas sofreu uma influência fundamental destas condições. O cenário externo desfavorável que caracterizou a maior parte do quadriênio 1999-2002 foi substituído por um ambiente benigno no âmbito das finanças e do comércio mundiais no período 2003-2007. No ano de 2008, contudo, o aprofundamento da crise financeira internacional resultou na reversão desse ambiente, com desdobramentos negativos sobre o desempenho do balanço de pagamentos brasileiro.

O trabalho está estruturado em mais três seções, além desta Introdução. $\mathrm{Na}$ sequência analisa-se, de forma sintética, a evolução das contas externas entre 1999 e 2007, com ênfase para a influência dos ciclos financeiros e de preços de commodities, exogenamente determinados. Posteriormente são detalhados os impactos da crise financeira global sobre os fluxos financeiros e comerciais. As considerações finais, além de consolidar os resultados, destacam a relação entre o comportamento financeiro e comercial recente e a solvência externa do Brasil, retirando daí implicações normativas para a redução de vulnerabilidades externas potenciais.

\section{UMA SÍNTESE SOBRE A EVOLUÇÃO DAS CONTAS EXTERNAS BRASILEIRAS DE 1999 A 2007}

Esta seção resgata, de forma sintética, as principais características das contas externas brasileiras no período após a adoção do regime de flutuação cambial (em janeiro de 1999) até o limiar do contágio da crise internacional sobre a economia brasileira (que ocorre a partir de 2008), com ênfase no quinquênio 2003-2007, caracterizado pelo ambiente externo benigno no âmbito do comércio e das finanças internacionais. A trajetória do Balanço de Pagamentos (BOP) sofreu importantes alterações no período em tela (ver Tabela 1). É possível identificar duas fases distintas desta trajetória.

A primeira fase (de 1999 a 2002) caracteriza-se pela escassez de fluxos de capitais de natureza financeira (investimentos de portfólio e empréstimos bancários) para o Brasil e os demais países emergentes, que se instala após as crises asiática, russa e brasileira. Esse quadriênio constituiu, na realidade, o período de baixa do primeiro ciclo de liquidez internacional da globalização financeira, que se inicia em 1990 e atinge seu auge em 2006. Assim, a ampliação do grau de abertura da economia brasileira na gestão Armínio Fraga Neto na presidência do $\mathrm{BCB}$ não teve efeitos concretos na

\footnotetext{
${ }^{2}$ Ver, dentre outros, Reinhart e Rogoff (2008) e Kregel (2008).
} 
primeira fase de vigência do regime de câmbio flutuante no Brasil ${ }^{3}$. Nesse contexto, os superávits da conta financeira ancoraram-se nos fluxos de investimento direto externo - IDE (associados, principalmente, à etapa final do processo de privatização) e nas operações de regularização com o FMI.

Uma segunda característica importante desta primeira fase refere-se aos resultados anuais deficitários das transações correntes. Isso porque os superávits comerciais após 2001 não foram suficientes para financiar o déficit da rubrica "Serviços e rendas", associado, sobretudo, às remessas de lucros e dividendos. O patamar historicamente elevado dessas remessas na economia brasileira (em função do seu alto grau de internacionalização produtiva) ampliou-se ainda mais devido à estratégia de política econômica adotada durante o regime de câmbio administrado (1994 e 1998), ancorada na ampliação da abertura financeira e da participação das empresas e bancos estrangeiros na economia brasileira. Esta estratégia viabilizou o financiamento do déficit da conta corrente neste período, mas, em contrapartida, resultou na ampliação do passivo externo do país (e, consequentemente, do seu serviço). O ingresso de capitais voluntários foi suficiente para financiar o saldo negativo dessa conta somente no ano 2000. Assim, na maior parte do período 1999-2002, o balanço de pagamentos voluntário apresentou déficit, que atingiu o recorde de US\$11,2 bilhões em 2002. Para fechar suas contas externas, o país recorreu aos empréstimos do FMI e, marginalmente, às reservas (pois, além do estoque reduzido, o acordo do FMI impunha um limite ao seu uso).

A segunda fase caracteriza-se por um contexto de abundância dos fluxos de capitais, associado ao novo ciclo de liquidez para os países emergentes (que emerge em 2003 e atinge seu pico em 2007) e resultados favoráveis nas transações comerciais e correntes com o exterior (associados à própria depreciação do período precedente, mas também ao forte crescimento do comércio internacional). Os déficits da conta financeira em 2004 e 2005 encobrem o comportamento de dois tipos de fluxos de capitais, subordinados a dinâmicas distintas: os capitais voluntários e as operações de regularização com o FMI. Em 2004 e, principalmente, 2005, o pagamento dos empréstimos aos FMI (contraídos entre 2001 e 2003) foi responsável por parte expressiva do déficit da conta financeira. Em 2005, se excluirmos esses empréstimos, essa conta foi superavitária. Já o déficit em 2006 na rubrica “investimento direto" decorreu da aquisição de uma mineradora no exterior pela Companhia Vale do Rio Doce (CVRD), que resultou em uma forte saída de recursos na modalidade "investimento direto brasileiro".

\footnotetext{
${ }^{3}$ A ampliação da abertura financeira da economia brasileira iniciou-se no final dos anos 1980, ainda no governo Sarney, e foi aprofundada nos anos 1990 e 2000. A Resolução do CMN 2.689 de 26/01/2000 ampliou ainda mais a integração financeira entre o país e o exterior ao flexibilizar as aplicações dos investidores estrangeiros nos mercados de ações e títulos de renda fixa e permitir o seu acesso, sem restrições, ao mercado de derivativos financeiros domésticos.
} 


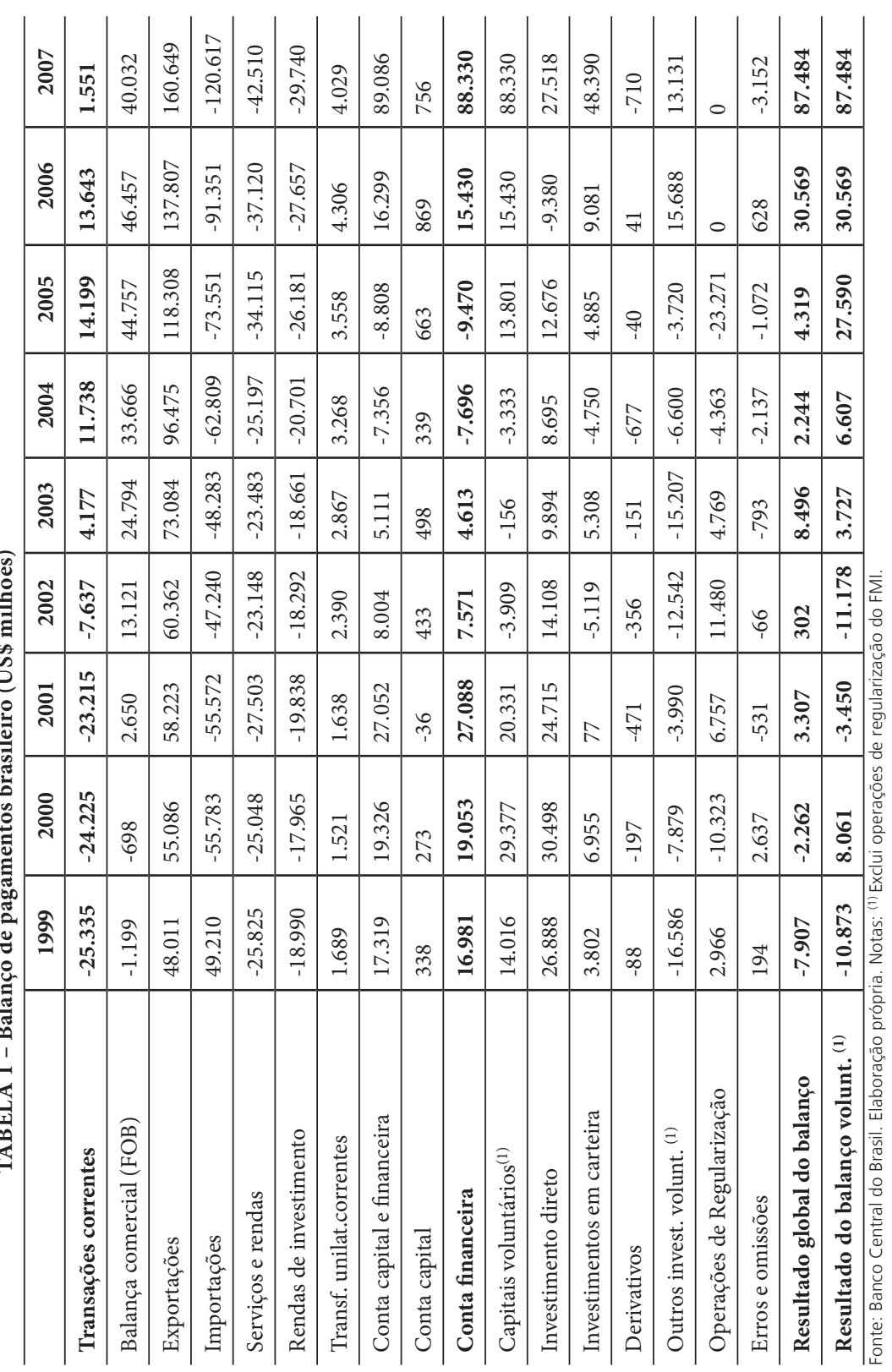


Assim, o desempenho dos fluxos financeiros e comerciais na segunda fase foi condicionado por algumas "heranças" da fase precedente, como pela adoção do regime de câmbio flutuante após a crise cambial de 1998/99, o acordo com o FMI, as depreciações cambiais subsequentes (em 2001 e 2002) e o aprofundamento da abertura financeira.

No período em análise, a evolução da conta financeira foi condicionada, essencialmente, pelos fluxos de capitais estrangeiros (Gráfico 1). Esses fluxos, por sua vez, refletiram a interação de quatro fatores:

i) o ciclo de liquidez internacional para os países emergentes;

ii) o grau de abertura financeira;

iii) a gestão das políticas monetária e cambial;

iv) a taxa de crescimento econômico doméstica.

Enquanto a dinâmica financeira internacional consiste no determinante, em última instância, desses fluxos - dada a posição subordinada e assimétrica da economia brasileira, assim como das demais economias periféricas, no sistema monetário e financeiro internacional -, os demais fatores internos, sejam os estruturais (grau de abertura financeira), sejam os macroeconômicos (políticas monetária e cambial e taxa de crescimento), constituem mediações dos impactos dessa dinâmica sobre o volume e a composição dos fluxos de capitais e do passivo externo do país.

A importância dessas mediações fica evidente quando comparamos a evolução dos fluxos líquidos de capitais privados para os países em desenvolvimento e a trajetória dos fluxos líquidos de capitais estrangeiros para o Brasil (Gráficos 2 e 3). Apesar de existir uma correspondência entre os dois movimentos, eles não são totalmente simétricos em razão, exatamente, da influência dos fatores internos, estruturais e conjunturais.

No início dos anos 1990, o processo de abertura financeira do governo Collor viabilizou a inserção da economia brasileira no primeiro ciclo de liquidez da globalização financeira. Foi exatamente o retorno dos fluxos de capitais privados para o país que permitiu o acúmulo de reservas internacionais entre 1992 e 1994, precondição para a adoção do Plano Real. Após 1998, quando o primeiro ciclo de liquidez entrou na sua fase de baixa, não ocorreu uma reversão simultânea dos fluxos de capitais para a economia brasileira devido, principalmente, às privatizações dos setores de telecomunicações e dos bancos públicos (com destaque para o Banespa), que resultaram no ingresso de IDE nesses setores. Já o aprofundamento da abertura financeira no ano 2000 não teve efeitos concretos sobre os fluxos financeiros para país, pois predominava nesse período um contexto de aversão do risco dos investidores globais e escassez de liquidez para os países em desenvolvimento. 
GRÁFICO 1 - CONTA FINANCEIRA ANUAL DO BRASIL (US\$ MILHÕES)

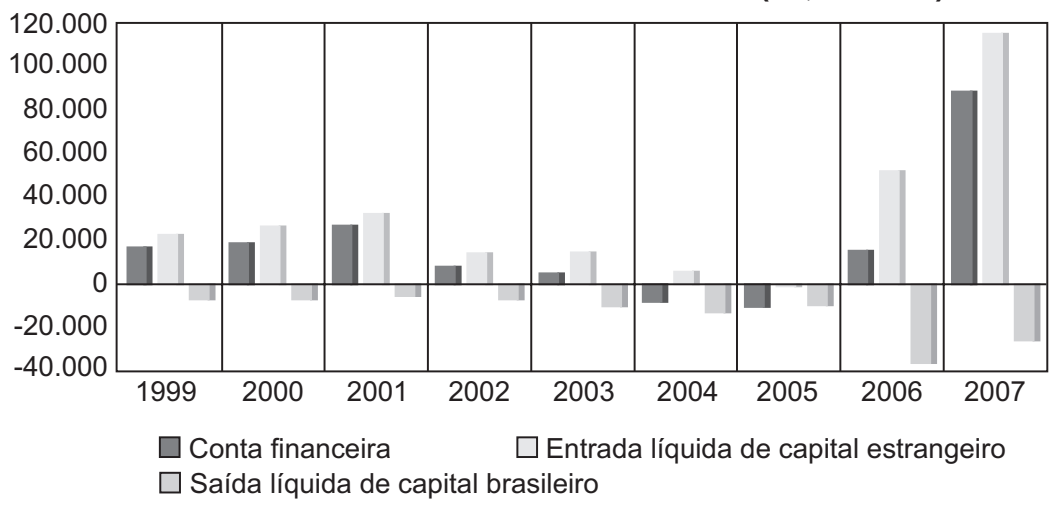

Fonte: Banco Central do Brasil. Elaboração própria.

\section{GRÁFICO 2 - FLUXOS DE CAPITAIS PARA OS PAÍSES EM DESENVOLVIMENTO (US\$ BILHÕES)}

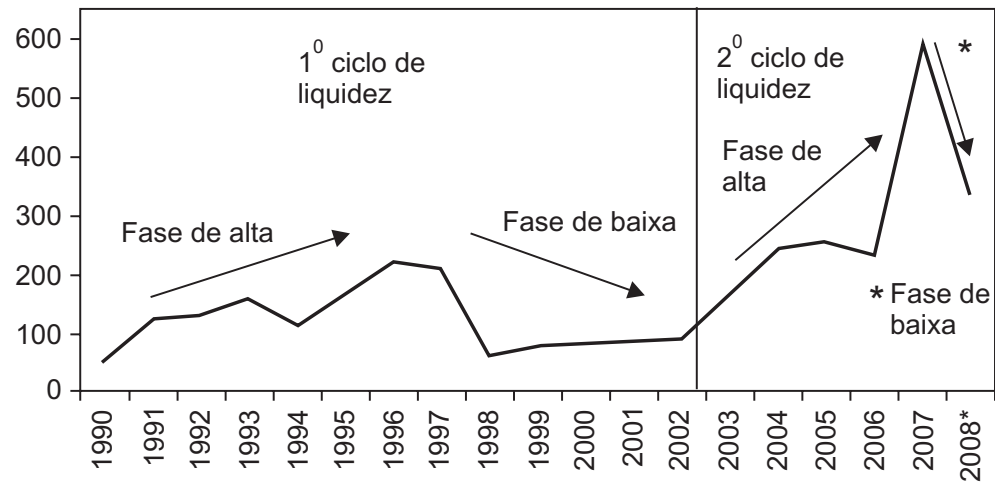

Fonte: Word Economic Outlook data base. International Monetary Fund. Elaboração Própria.

GRÁFICO 3 - FLUXOS DE CAPITAIS ESTRANGEIROS PARA O BRASIL (US\$ MILHÕES)

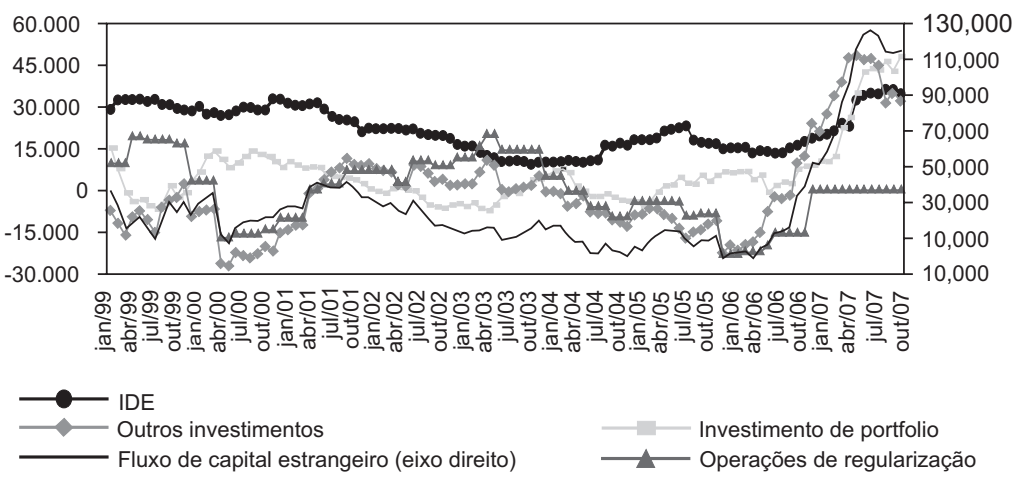

Fonte: Banco Central do Brasil. Elaboração própria. 
No caso do segundo ciclo de liquidez, que emerge em 2003, também não se observa uma evolução pari passu dos fluxos privados de capitais e da entrada líquida de recursos para o país. Ou seja, o impacto das condições favoráveis de liquidez internacional sobre o desempenho da conta financeira brasileira não foi imediato. Em 2003 e 2004, os fluxos líquidos de capitais voluntários foram negativos. Porém, essas condições aliviaram a restrição externa e permitiram o pagamento dos compromissos com o FMI neste último ano. Em 2005, esses fluxos apresentaram resultado positivo, ancorado não somente no ingresso de IDE, mas também nos investimentos de portfólio. A conta capital e financeira foi negativa, em mais de US\$ 9 bilhões, devido à quitação do empréstimo com o FMI, realizado a partir de divisas adquiridas no mercado de câmbio, o que explica o menor resultado global do balanço de pagamentos.

Já no biênio 2006-2007, o desempenho da conta financeira foi condicionado, exclusivamente, pela dinâmica dos fluxos de capitais voluntários. Mais especificamente, como, no caso do Brasil, a internacionalização produtiva e financeira é assimétrica - os investimentos e empréstimos de residentes para o exterior ainda têm uma pequena dimensão, enquanto os investimentos e empréstimos de não-residentes são muito elevados -, aquele desempenho subordinou-se ao ingresso líquido de recursos externos no país.

Como revela o Gráfico 3, este ingresso tem um forte crescimento em 2006 e, especialmente, 2007, quando atinge US\$ 114,6 bilhões, valor recorde em termos históricos. Nesse último ano, a fase de alta do ciclo recente de liquidez também alcança o seu auge (ver Gráfico 2). Assim, apesar de ter se acoplado com um certo atraso neste ciclo, em 2007 a economia brasileira aproveitou ao máximo o boom de capitais externos para os países emergentes. Além das condições externas favoráveis, um conjunto de fatores internos estimulou a entrada de capitais estrangeiros no país.

A interação entre fatores internos e externos condicionou o desempenho das três principais modalidades de fluxos de capitais no período em tela. $\mathrm{Na}$ análise desses fluxos, vale lembrar a lógica diferenciada dos fluxos financeiros (investimento de portfólio e outros investimentos) em relação ao IDE, vinculados às perspectivas de crescimento econômico nos países de origem e de destino, bem como às estratégias das Empresas Transnacionais (ETs).

O crescimento dos fluxos de IDE para o Brasil após 2004, liderado pela modalidade Participação no Capital, insere-se emum movimento de retomada dos investimentos das ETs para os países em desenvolvimento (UNCTAD, 2008), estimulado pelo dinamismo econômico desses países e pela alta dos preços das commodities. No caso da economia brasileira, a conjunção desses dois fatores ocorreu somente em 2007 e explica, em grande parte, a forte expansão dos fluxos de IDE neste ano, que atingiu US\$ 34,6 bilhões, um crescimento de 83\% frente a 2006. 
Assim como os fluxos de IDE, o ingresso líquido de capitais nas modalidades de "Investimentos de Portfólio" e "Outros Investimentos" registrou forte crescimento em 2007. No caso desses fluxos financeiros, nos anos anteriores, o desempenho das diversas modalidades de fluxos foi bastante heterogêneo. Em 2005, observa-se crescimento somente das aquisições de ações na Bolsa de Valores de São Paulo (Bovespa) - estimuladas pelas perspectivas de lucro com as ações negociadas no mercado acionário doméstico - e dos créditos comerciais de curto prazo (dado o elevado diferencial entre os juros internos e externos). Em 2006, por sua vez, com a edição da MP281 em fevereiro, que concedeu incentivos tributários aos investidores estrangeiros para a aquisição de títulos da dívida pública interna, as aplicações nesses títulos apresentaram uma recuperação significativa e praticamente instantânea .

\section{O EFEITO-CONTÁGIO DA CRISE INTERNACIONAL SOBRE AS CONTAS EXTERNAS BRASILEIRAS}

A crise financeira atual, que se originou no mercado subprime norte-americano em julho de 2007, contaminou, logo nos seus primeiros meses, os demais países desenvolvidos. No primeiro semestre de 2008 começou a se espraiar para alguns países emergentes, mas, somente em meados de setembro, quando ela se converteu em um fenômeno sistêmico, observou-se seu transbordamento praticamente generalizado para esses países. Nem mesmo aqueles com bons fundamentos e políticas econômicas consideradas saudáveis ficaram incólumes.

O efeito-contágio da crise sobre as regiões emergentes ocorreu mediante vários canais de transmissão - que derivam das múltiplas relações de interdependência entre as economias emergentes e avançadas -, muitos dos quais se autorreforçaram (CEPAL, 2008; IMF, 2008; ROSALES, 2010). Dentre os mecanismos de transmissão que surtiram impacto direto sobre os mercados de câmbio e o balanço de pagamentos, destacam-se:

i) a retração dos investimentos de portfólio em um contexto de crescente aversão ao risco e preferência pela liquidez;

ii) a diminuição e, após a falência do Lehman Brothers, a virtual interrupção dos créditos externos, inclusive daqueles direcionados ao comércio exterior;

iii) a queda dos fluxos de IDE diante da desaceleração nos países avançados;

iv) a redução da demanda externa desses países e dos preços das commodities;

v) o aumento das remessas de lucros pelas filiais das ETs e dos bancos estrangeiros;

vi) a redução das transferências unilaterais dos imigrantes.

Dois canais adicionais, que não têm impacto direto sobre as contas externas, verificaram-se em alguns casos: a retração mais forte do crédito interno pelas filiais dos bancos estrangeiros, e; as operações com derivativos cambiais, que tiveram um papel importante nas depreciações cambiais na Coréia, Brasil e México. 
O impacto desses canais, todavia, foi heterogêneo entre as economias emergentes devido a um conjunto de características específicas - dentre os quais, os graus de abertura financeira e comercial, a estrutura da pauta de comércio exterior, os regimes cambial e monetário, o grau de vulnerabilidade externa e de descasamento de moedas; a situação das contas públicas - bem como às respostas de política econômica. Se, em um primeiro momento (especificamente, no último trimestre de 2008), o efeito-contágio da crise atingiu todas as moedas emergentes de forma praticamente indiscriminada, ao longo de 2009 as diferentes situações macroeconômicas (especialmente, os resultados em transações correntes e das contas públicas e a proporção do endividamento externo ou doméstico em moeda estrangeira) condicionaram não somente as trajetórias das taxas de câmbio e de juros e dos níveis de atividade e emprego, mas também o grau de liberdade e a eficácia das iniciativas anticíclicas de política econômica.

No segundo semestre de 2009 - quando emergiu uma nova etapa da crise global, caracterizada pela melhoria significativa dos mercados e instituições financeiras e pela recuperação das economias avançadas (IMF, 2010) -, a liquidez abundante, as taxas de juros oficiais historicamente baixas e a menor aversão ao risco dos investidores fomentaram os fluxos de capitais para as economias emergentes com melhor situação macroeconômica, os quais já ensaiavam uma retomada no primeiro semestre do ano. Adicionalmente, aquela recuperação (mesmo que ainda frágil) teve efeitos positivos sobre o comércio mundial e, assim, sobre as exportações destas economias. Nesse contexto, dois importantes canais de transmissão da crise deixaram de atuar no caso de vários países emergentes, convertendo-se, novamente, em fontes de estímulo (para os mercados financeiros ou para atividade produtiva) e/ou resultando em outros desafios para a política econômica (como a necessidade de impor restrições aos fluxos de capitais diante da trajetória de apreciação cambial). Assim como os mecanismos de contágio na fase de aprofundamento da crise, o retorno dos fluxos de capitais e a evolução mais favorável do comércio mundial também tiveram implicações diferenciadas sobre os diversos países emergentes, em função das mesmas características mencionadas acima.

Nas seções 3.1 e 3.2, analisa-se o efeito-contágio da crise sobre, respectivamente, os fluxos de capitais e o comércio exterior brasileiro.

\subsection{PANORAMA DAS CONTAS EXTERNAS E DOS FLUXOS DE CAPITAIS NO BIÊNIO 2008-2009}

As contas externas brasileiras tiveram uma evolução bastante distinta nos dois anos marcados pelo efeito-contágio da crise econômica e financeira mundial. Enquanto em 2008 o balanço de pagamentos brasileiro foi superavitário em somente US\$2,97 bilhões, em 2009 este balanço foi superavitário em US\$ 46,6 bilhões, segundo maior valor da série histórica do BCB, perdendo apenas para o resultado recorde de 2007 (ver Tabela 2). A seguir, detalham-se os condicionantes desta trajetória diferenciada. 
O balanço de pagamentos em 2008 conseguiu lograr um resultado positivo graças ao superávit de US\$28.297 milhões da conta financeira, que foi mais do que suficiente para financiar o déficit de US\$28.192 milhões das transações correntes, o primeiro desde 2002 e o pior resultado desde 1999 (associado tanto à deterioração da balança comercial, como ao aumento das remessas de lucros e dividendos em um contexto de aceleração do crescimento econômico até o terceiro trimestre do ano).

O superávit da conta financeira em 2008, embora 63,9\% inferior à cifra de US $\$ 88,3$ bilhões registrada em 2007, foi o terceiro maior da série história do BCB, superando os resultados de 2005 e 2006 (ver Tabela 1), quando os fluxos de capitais para os países emergentes tiveram um melhor desempenho do que em 2008, que marca o início da fase de baixa do ciclo de liquidez da presente década. Obtido graças ao ingresso líquido de capitais estrangeiros no valor de US\$ 52,4 bilhões, este superávit pode ser considerado elevado diante do contexto externo adverso.

Um conjunto de fatores externos e internos contribuiu para atenuar a retração dos fluxos de capitais estrangeiros para o Brasil em 2008 (e, assim, o contágio da crise sobre a evolução da taxa de câmbio brasileira até setembro). Em primeiro lugar, a performance do investimento direto estrangeiro (IDE) foi excepcional. Este atingiu o valor recorde em termos históricos de US\$ 45 bilhões, sendo a única modalidade de capital externo que cresceu em 2008 em relação a 2007 (em torno de 30\%). Apesar da menor participação no total dos empréstimos intercompanhias (de 33,3\%), eles responderam por $61,3 \%$ desse crescimento devido à sua taxa de expansão mais elevada, de $76,2 \%$ frente à taxa de $15,3 \%$ da modalidade participação no capital.

A distribuição dos ingressos brutos de IDE (Tabela 3) evidencia que o perfil setorial manteve a tendência observada em 2007. Esses ingressos foram estimulados pelas perspectivas de lucro nos setores produtores de commodities (principalmente extrativa mineral e biocombustíveis) e nas indústrias baseadas em recursos naturais (como metalurgia e produtos alimentícios), dada a trajetória altista dos preços desses bens até meados de 2008, que constituiu, em certa medida, um dos efeitos colaterais da crise financeira internacional, bem como pelo maior dinamismo do mercado interno, que favoreceu investimentos nas indústrias automobilística e de máquinas e equipamentos.

Já os fluxos financeiros retraíram-se $87,6 \%$ na comparação com 2007. A queda foi mais intensa no caso dos "Investimentos de portfólio", que registraram saída líquida de US\$ 767 milhões, em função do resgate das aplicações em ações no país pelos investidores estrangeiros e do pagamento de títulos emitidos no exterior. Em contrapartida, a modalidade "Outros investimentos", que inclui os empréstimos contratados junto a bancos e organismos multilaterais, ainda obteve um saldo positivo de US\$ 8,1 bilhões (contudo, 74,3\% menor que o observado em 2007), ancorado no ingresso líquido de empréstimos e financiamentos de longo prazo (US\$13,3 bilhões), já que as modalidades de curto prazo tiveram um desempenho desfavorável, especialmente a "Empréstimos e financiamentos - demais setores CP (curto prazo)", que 
se refere à captação de recursos no exterior pelos bancos para realizar operações de arbitragem de juros ou conceder crédito ao comércio exterior (Tabela 2).

TABELA 2 - Balanço de Pagamentos Brasileiro 2007-2009 (US\$ milhões)

\begin{tabular}{|c|c|c|c|}
\hline & 2007 & 2008 & 2009 \\
\hline Resumo do balanço & 87.484 & 2.969 & 46.651 \\
\hline Transações correntes & 1.551 & -28.192 & -24.334 \\
\hline Balança comercial & 40.032 & 24.836 & 25.347 \\
\hline Serviços e rendas & -42.510 & -57.234 & -52.945 \\
\hline Serviços & -13.219 & -16.672 & -19.260 \\
\hline Rendas de investimento & -29.740 & -41.107 & -34.287 \\
\hline Conta capital e financeira & 89.086 & 29.352 & 70.551 \\
\hline Conta financeira & 88.330 & 28.297 & 69.423 \\
\hline Saida de capitais brasileiros & -25.332 & -24.138 & -19.926 \\
\hline Fluxo de capitais estrangeiros & 114.372 & 52.435 & 89.348 \\
\hline Investimento estrangeiro direto & 34.585 & 45.058 & 25.949 \\
\hline Participação no capital & 26.074 & 30.064 & 19.906 \\
\hline Empréstimos intercompanhias & 8.510 & 14.994 & 6.042 \\
\hline Fluxos financeiros & 79.787 & 7.377 & 63.400 \\
\hline Investimento estrangeiro de portifólio & 48.104 & -7.67 & 46.159 \\
\hline Ações no país & 24.613 & -10.850 & 32.097 \\
\hline Renda fixa no país & 20.482 & 15.289 & 10.077 \\
\hline Ações no exterior & 1.604 & 3.285 & 4.974 \\
\hline Renda fixa no exterior & 1.405 & -8.491 & -989 \\
\hline Bônus & -7.880 & -3.003 & 94 \\
\hline Notes e commercial paper & 5.633 & -1.552 & -516 \\
\hline Títulos curto prazo & 3.651 & -3.935 & -5.67 \\
\hline Outros investimentos estrangeiros & 31.683 & 8.143 & 17.241 \\
\hline Crédito comercial-fornecedores CP & 17.378 & 3.966 & 5.145 \\
\hline Emprést. e financiam. de mais setores CP & 13.770 & -8.148 & 1.486 \\
\hline Emprést. e financiam. de mais setores LP & 64 & 13.321 & 7.175 \\
\hline
\end{tabular}

Fonte: Banco Central do Brasil. Elaboração própria. 
TABELA 3 - Participação no capital - Ingressos brutos

\begin{tabular}{l|c|c|c|c|c|c}
\hline & \multicolumn{3}{|c|}{ US\$ milhões } & \multicolumn{3}{c}{ Particip. total \% } \\
\hline & $\mathbf{2 0 0 7}$ & $\mathbf{2 0 0 8}$ & $\mathbf{2 0 0 9}$ & $\mathbf{2 0 0 7}$ & $\mathbf{2 0 0 8}$ & $\mathbf{2 0 0 9}$ \\
\hline Total & $\mathbf{3 4 . 3 3 5}$ & $\mathbf{4 4 . 4 5 7}$ & $\mathbf{3 1 . 6 7 9}$ & $\mathbf{1 0 0 , 0}$ & $\mathbf{1 0 0 , 0}$ & $\mathbf{1 0 0 , 0}$ \\
Agricultura, pecuária e extrat. mineral & $\mathbf{4 . 7 5 1}$ & $\mathbf{1 2 . 9 9 5}$ & $\mathbf{4 . 5 8 1}$ & $\mathbf{1 3 , 8}$ & $\mathbf{2 9 , 2}$ & $\mathbf{1 4 , 5}$ \\
$\quad$ Extração de petróleo e gás natural & 797 & 1.339 & 2.655 & 2,3 & 3,0 & 8,4 \\
$\quad$ Extração de minerais metálicos & 3.073 & 10.645 & 1.299 & 8,9 & 23,9 & 4,1 \\
Industria & $\mathbf{1 3 . 4 8 1}$ & $\mathbf{1 4 . 0 1 3}$ & $\mathbf{1 3 . 4 6 5}$ & $\mathbf{3 9 , 3}$ & $\mathbf{3 1 , 5}$ & $\mathbf{4 2 , 5}$ \\
$\quad$ Metalurgia e siderurgia & 4.699 & 4.984 & 3.753 & 13,7 & 11,2 & 11,8 \\
$\quad$ Veículos, reboques e carrocerias & 861 & 964 & 2.163 & 2,5 & 2,2 & 6,8 \\
$\quad$ Coque, derivados de petróleo e & 1.644 & 1.568 & 1.344 & 12,2 & 3,5 & 4,2 \\
biocombustível & & & & & & \\
Produtos alimentícios & 1.752 & 2.226 & 450 & 5,1 & 5,0 & 1,4 \\
Prod. de borracha e material plástico & 494 & 671 & 436 & 1,4 & 1,5 & 1,4 \\
$\quad$ Máquinas e equipamentos & 454 & 651 & 388 & 1,3 & 1,5 & 1,3 \\
Serviços & $\mathbf{1 6 . 1 0 3}$ & $\mathbf{1 7 . 4 4 9}$ & $\mathbf{1 3 . 6 3 4}$ & $\mathbf{4 6 , 9}$ & $\mathbf{3 9 , 2}$ & $\mathbf{4 3 , 0}$ \\
\hline
\end{tabular}

Fonte: Banco Central do Brasil. Elaboração própria.

No caso dos fluxos financeiros, alguns fatores contribuíram para sustentá-los nos primeiros oito primeiros meses de 2008 e, assim, amortecer o resultado anual desfavorável, associado, sobretudo, ao desempenho do quarto trimestre, quando o setor externo brasileiro é contaminado pelo efeito-contágio da crise financeira internacional. Por um lado, os investimentos de portfólio em ações de empresas brasileiras foram impulsionados no primeiro semestre pela forte alta dos preços das commodities e pela elevação da classificação do risco de crédito soberano do Brasil para "grau de investimento" pela agência internacional de classificação de risco de crédito Standard \& Poors (S\&P) no dia 30 de abril (seguida pela agência Fitch no dia 29 de maio de 2008), que provocou uma euforia de curta duração nos mercados de ativos brasileiros, em particular, pela falta de antecipação do movimento.

As aplicações em títulos públicos de renda fixa no país foram estimuladas pelo aumento do diferencial entre os juros interno e externo, decorrente da alta da taxa Selic a partir de abril em um contexto de quedas sucessivas da taxa de juros americana. Com isso, a alíquota de 1,5\% do Imposto sobre Operações Financeiras (IOF) sobre aplicações de não-residentes em títulos públicos, que vigorou entre abril e 10 de outubro (quando essa alíquota foi reduzida a zero), revelou-se insuficiente para reduzir a atratividade das aplicações em renda fixa. Esse aumento estimulou, igualmente, as captações externas de curto prazo pelas empresas (na modalidade crédito comercial - fornecedores) e pelos bancos (mediante empréstimos e financiamentos de curto prazo) (ver Tabela 2). Como mostra o Gráfico 4, o diferencial entre a taxa básica de juros brasileira (taxa Selic) e sua congênere nos Estados Unidos (Fed Fund 
Rate), somado à apreciação cambial no período, proporcionou até agosto uma alta rentabilidade às operações de arbitragem realizadas sem hedge cambial. Em contrapartida, no último trimestre do ano, o elevado diferencial de juros não foi suficiente para neutralizar o efeito negativo sobre esta rentabilidade da depreciação cambial.

GRÁFICO 4 - PARIDADE COBERTA, DIFERENCIAL DE JUROS E VARIAÇÃO CAMBIAL (\%)

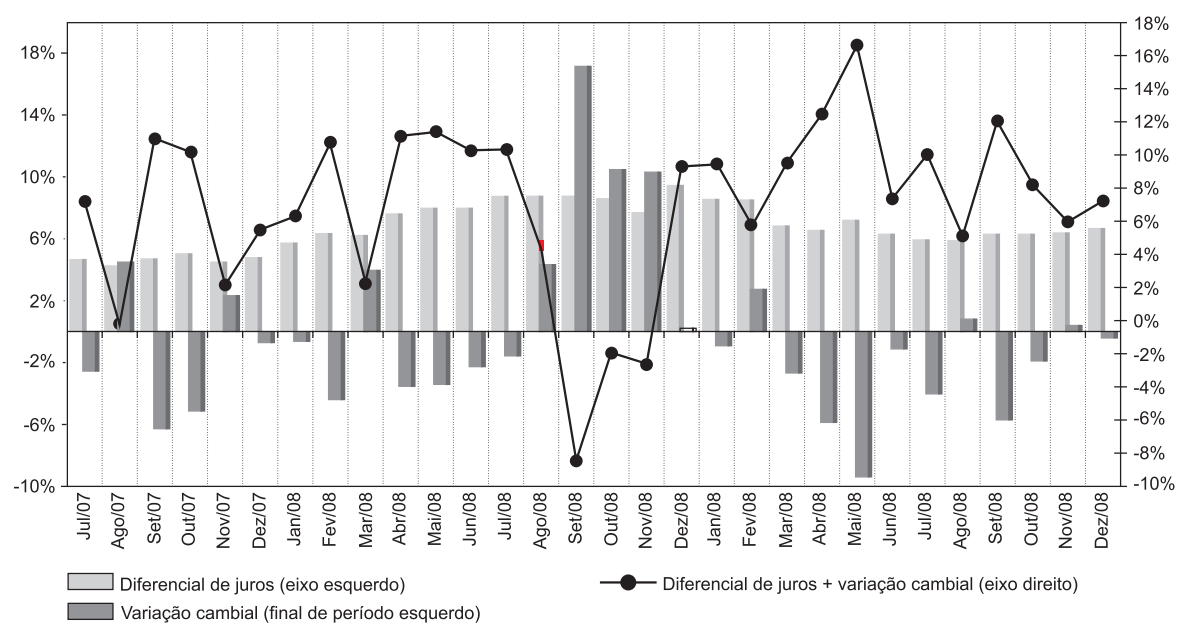

Fonte: BCB e Fed. Elaboração própria.

Em 2009, o resultado favorável do balanço de pagamentos também foi garantido pelo desempenho da conta financeira, que atingiu R\$ 69,4 bilhões - 145,3\% superior ao registrado em 2008 e o segundo resultado mais elevado desta série -, que foi mais do que suficiente para financiar o déficit de US\$24,3 bilhões nas transações correntes. Este déficit recuou $13,7 \%$ frente ao observado no ano anterior, devido à ligeira melhora da balança comercial $(+2,1 \%)$ e, sobretudo, à retração do saldo negativo da conta de serviços e rendas $(-7,4 \%)$ - associada à queda das remessas líquidas de rendas de investimento (estrangeiro direto e de portfólio) em $16,6 \%$, que são pró-cíclicas.

A melhora expressiva da conta financeira decorreu, sobretudo, do forte crescimento do ingresso de recursos externos, que atingiu US\$ 89,3 bilhões, cifra 70,4\% superior à registrada no ano anterior. Também contribuiu para essa melhora a menor saída de capitais brasileiros para o exterior, que recuou 17,5\% na comparação com 2008 (ver Tabelas 2 e 3), devido ao retorno líquido de investimentos brasileiros (principalmente diretos e, em menor medida, de portfólio), em um contexto de baixas oportunidades de lucro nos países avançados e de perspectivas favoráveis em relação à economia brasileira, que revelou uma capacidade inédita de resistência ao efeito-contágio da crise. 
Além do avanço quantitativo, a composição do ingresso de recursos externos também sofreu importantes alterações em 2009. Ao contrário de 2008, quando o IDE respondeu por mais de $80 \%$ do total, em 2009, sua participação recuou para 29\%. Assim, a abundância de fluxos de capitais em 2009 decorreu, principalmente, dos fluxos financeiros, que somaram US $\$ 63,4$ bilhões, equivalentes a $71 \%$ do total (ver Tabelas 2 e 3). No âmbito desses fluxos, os investimentos de portfólio foram o destaque, atingindo US $\$ 46,2$ bilhões (52\% do total). Já os “Outros investimentos estrangeiros" atingiram US $\$ 17,2$ bilhões (27,2\% do total), cifra $111,7 \%$ superior à observada em 2008.

A absorção de um volume significativo de fluxos de capitais externos de natureza financeira pela economia brasileira em 2009 inseriu-se em um movimento mais geral de retorno desses fluxos para algumas economias emergentes (sobretudo, asiáticas e latino-americanas) ao longo de 2009, o qual foi mais rápido e intenso do que o previsto pela maioria dos analistas (IIF, 2010, IMF, 2010). As captações externas, bem como as aplicações em títulos públicos de renda fixa no país, foram estimuladas pelo elevado diferencial entre os juros interno e externo, decorrente da manutenção da meta da taxa Selic em um patamar elevado em um contexto de taxas de juros próximas a zero nos países avançados. O ganho em dólar dos investidores estrangeiros (o diferencial de juros somado à variação cambial) manteve-se positivo ao longo do ano e superou este diferencial em quase todos os meses (exceto em fevereiro - ver Gráfico 4).

Ao contrário dos fluxos financeiros, o ingresso líquido de IDE somou US\$25,9 bilhões, cifra $42,4 \%$ inferior à registrada em 2008. Este recuo - inflado pelo valor excepcionalmente elevado da base de comparação, recorde da série histórica do BCB - já era esperado diante da recessão nos países avançados e à desaceleração do crescimento da economia brasileira, já que essa modalidade de capital estrangeiro é prócíclica em relação à evolução macroeconômica tanto do país de origem, como do país de destino dos investimentos. Ademais, em 2009, a necessidade de liquidez e as dificuldades de financiamento das matrizes sediadas nos países avançados também contribuíram para a contração dos empréstimos intercompanhias (em 59,7\%), que foi mais intensa do que a registrada nos aportes em participação do capital (em 33,8\%). A despeito da retração em relação aos resultados de 2008 (e também de 2007), de acordo com a Unctad (2009), o Brasil manteve a liderança na absorção de IDE na América Latina. A análise da distribuição setorial dos ingressos brutos de IDE (ver Tabela 3) revela que, assim como em 2007 e 2008, a dimensão do mercado interno brasileiro e as perspectivas de lucro em alguns setores ligados a commodities (devido à retomada da trajetória altista dos preços e às reservas do pré-sal) constituíram os principais fatores de atração dos investimentos em participação de capital. 


\subsection{O EFEITO-CONTÁGIO DA CRISE SOBRE O COMÉRCIO EXTERIOR BRASILEIRO}

O saldo comercial brasileiro sofreu uma forte deterioração nos dois anos em foco, na comparação com o desempenho registrado no triênio anterior, mas ainda se manteve positivo (próximo ao de 2003), e, assim, contribuiu para o superávit do balanço de pagamentos em um contexto internacional adverso (ver Tabela 1). Todavia, embora os resultados de 2008 e 2009 sejam próximos em termos de valores, seus determinantes foram distintos. Enquanto, em 2008, o recuo de 37,7\% do superávit comercial decorreu do maior ritmo de crescimento das importações relativamente às exportações (44\% e 23\% frente ao ano anterior, respectivamente), em 2009, em contrapartida, o ligeiro avanço deste superávit (de 1,3\%) foi determinado pela maior retração das importações vis-à-vis às exportações $(26,2 \%$ e $22,7 \%$, respectivamente, frente a 2008), como detalhado a seguir.

Em 2008, a evolução do comércio exterior brasileiro foi determinada pela trajetória de duas variáveis macroeconômicas (taxa de câmbio e o nível de atividade), que se mantiveram imunes ao efeito-contágio da crise internacional até agosto, bem como pelos canais de transmissão desta crise, que se metamorfosearam ao longo do ano, dentre os quais se destacam: a alta dos preços das commodities até agosto, seguida de deflação a partir deste mês; o recuo da demanda externa, que se intensificou ao longo do ano; a depreciação cambial, e; a forte desaceleração econômica a partir de setembro. A queda do saldo comercial decorreu, principalmente, da interação entre a apreciação do real no primeiro semestre do ano e o maior dinamismo da economia brasileira até o terceiro trimestre, que, simultaneamente, impulsionou as importações e desestimulou as exportações (ver Gráficos 5 e 6). Em primeiro lugar, a trajetória de forte e ininterrupta valorização continuou comprometendo progressivamente a competitividade das exportações brasileiras e, ao baratear os produtos importados, incentivou o seu uso em substituição aos bens e insumos nacionais. Em segundo lugar, a aceleração do crescimento econômico a partir de 2007, ancorada na demanda interna, aumentou ainda mais a atratividade do mercado doméstico para aquelas empresas e, dada a elevada elasticidade-renda das importações na economia brasileira, provocou um forte vazamento dos gastos para o exterior (ver Gráfico 6). 
GRÁFICO 5 - VARIAÇÃO DA TAXA DE CÂMBIO REAL EFETIVA (\%)

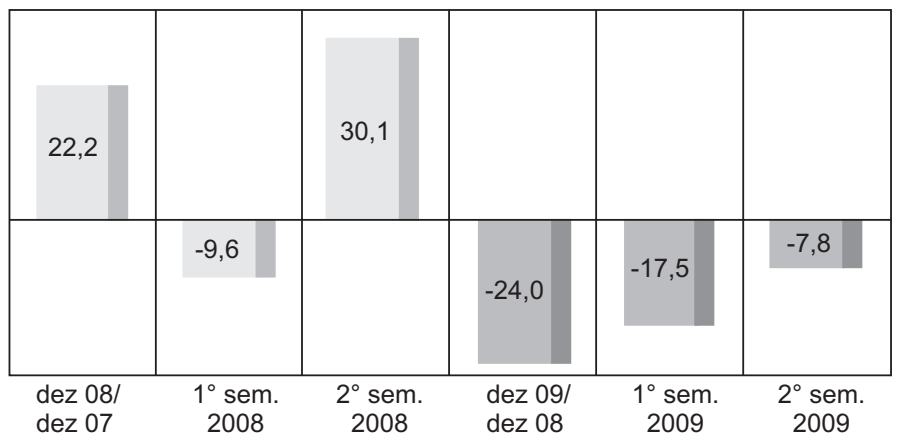

Fonte: Funcex. Elaboração própria.

GRÁFICO 6 - PIB: VARIAÇÃO FRENTE AO MESMO TRIMESTRE DO ANO ANTERIOR (EM \%)

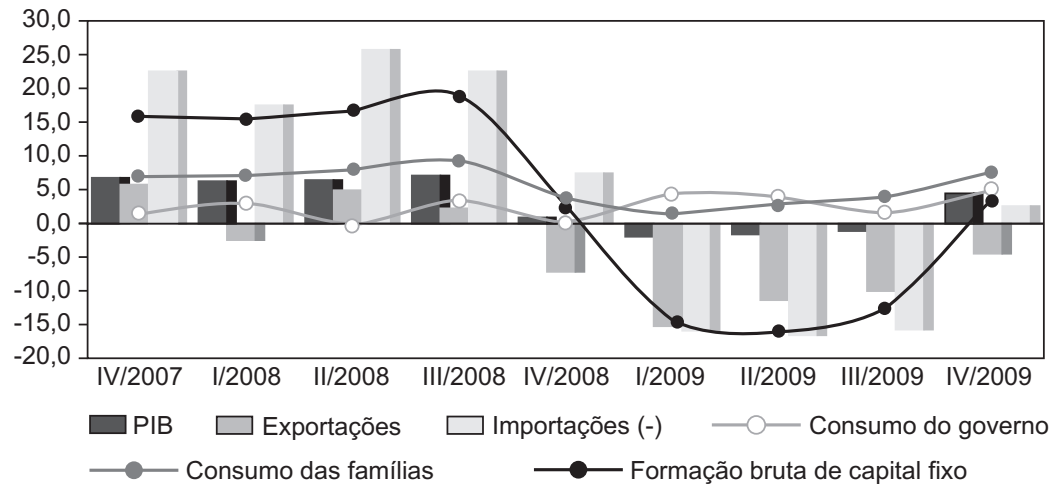

Fonte: IBGE. Elaboração própria.

A reversão das tendências de natureza macroeconômica sintetizadas acima após o aprofundamento da crise em setembro - que resultou em depreciação do real e forte desaceleração da atividade econômica, dois importantes canais de contágio a partir de então - não surtiu efeito positivo sobre o saldo suficiente para contrabalançar a sua deterioração até agosto. Ou seja, considerando o ano de 2008 como um todo, o efeito líquido da evolução das variáveis macroeconômicas (taxa de câmbio e do PIB) sobre a balança comercial foi negativo, em função, em grande parte, da resposta defasada do saldo comercial a essas variáveis, com destaque para a depreciação cambial (associada à precedência dos contratos de exportação em relação aos embarques efetivos e ao período de tempo necessário para identificar compradores no exterior). Ademais, no último trimestre de 2008, a forte desaceleração da atividade econômica nas economias da OCDE e nos principais países emergentes (IIF, 2010, IMF, 2010), ao comprometer a demanda externa pelos produtos brasileiros, certamente atenuou (ou mesmo anulou), o efeito positivo da desvalorização do real sobre as exportações. 
A retração ou desaceleração das economias avançadas e emergentes contaminou o volume das exportações mundiais, que aumentou somente 4,1\% em 2008 frente ao ano anterior, percentual mais baixo desde 2002. Este volume também foi afetado pela virtual paralisia do mercado de crédito internacional após a falência do Lehman Brothers, que envolveu, inclusive, as linhas de financiamento ao comércio exterior. Todavia, o desempenho do comércio mundial em termos de valor foi melhor do que em 2007, devido à maior taxa de crescimento das vendas externas dos países emergentes (IMF, 2010).

O desempenho mais favorável das exportações dos países emergentes, por sua vez, decorreu da aceleração do ritmo de crescimento dos preços das commodities até meados do ano, que constituiu um dos primeiros efeitos colaterais da crise financeira internacional. Isso porque os fundos de investimento mais especulativos, em um contexto de queda da taxa de juros nos Estados Unidos, ampliaram suas aplicações nos mercados futuros de commodities no segundo semestre de 2007 e primeiro de 2008 no afã de obter lucros e atenuar suas perdas nas aplicações vinculadas às hipotecas subprime, o que exerceu uma pressão altista sobre as cotações. A partir de junho, as perspectivas de retração da demanda mundial de bens e serviços afetaram negativamente os preços desses bens, que ingressaram em uma trajetória de queda, a qual, contudo, não chegou a anular os ganhos registrados no primeiro semestre no caso do índice geral e de vários subíndices (ver Gráfico 7).

A análise do desempenho dos preços e das quantidades exportadas e importadas contribuiu para elucidar o impacto líquido dos mecanismos de transmissão da crise internacional sobre a balança comercial em 2008 que, como já anunciado, mudaram de natureza e de intensidade na medida em que esta crise se aprofundava. Defende-se a hipótese de que este impacto foi positivo por duas razões principais. 
GRÁFICO 7 - EVOLUÇÃO DOS ÍNDICES DE PREÇO DAS COMMODITIES (2005 = 100)

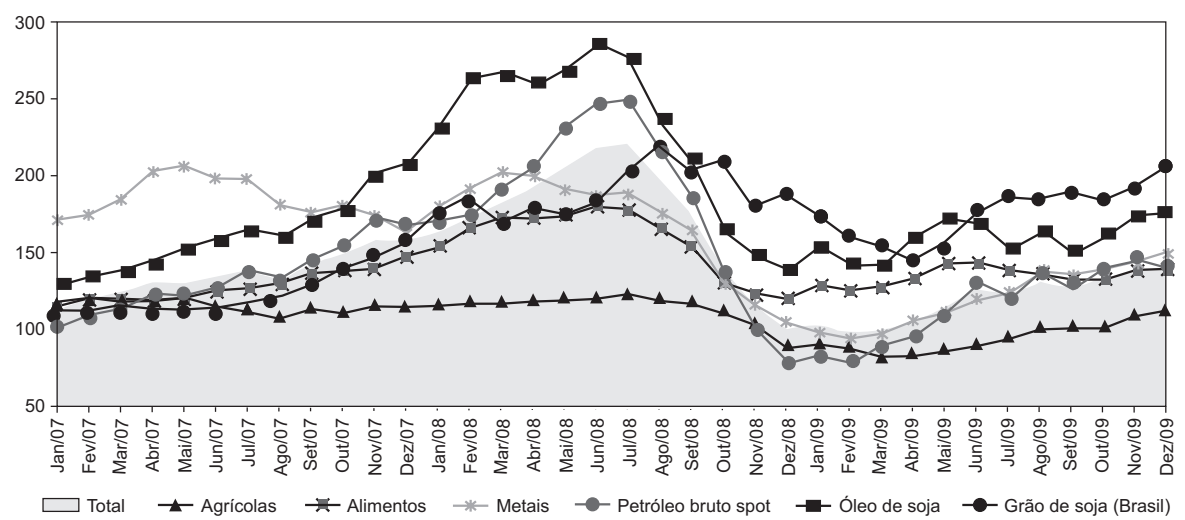

Fonte: IFS-FMI. Elaboração própria.

Por um lado, a despeito da deflação nos mercados de commodities a partir de agosto, tanto os preços das exportações brasileiras (que atingiram seu pico histórico nesse mês, segundo a Funcex, 2009) como os termos de troca registraram alta em 2008. No acumulado de janeiro a dezembro (frente ao mesmo período do ano anterior), os preços das exportações cresceram $26,3 \%$ e garantiram uma expansão de $23,2 \%$ das vendas externas em valor, a despeito da queda de 2,5\% das quantidades (que não ocorria desde 2002) (ver Gráfico 8). Esta queda também tinha ocorrido no primeiro semestre do ano e deve ser atribuída, muito mais, aos efeitos adversos da apreciação da moeda doméstica do que à retração da demanda externa e dos créditos comerciais, dadas as defasagens envolvidas. Os termos de troca também fecharam o ano com variação positiva, de 3,4\%, a despeito da queda no último trimestre, segundo cálculos da Fundação de Comércio Exterior (Funcex).

Por outro lado, no âmbito das importações, o crescimento teria sido maior se a economia brasileira não tivesse sofrido uma forte desaceleração no último trimestre do ano (quando o PIB recuou 3,6\% frente ao trimestre anterior com ajuste sazonal). Caso este canal de contágio não tivesse se manifestado, o índice de quantum das importações, provavelmente, teria sustentado sua trajetória ascendente até o final do ano e se expandido em um percentual superior ao registrado que foi impulsionado, sobretudo, pelas importações de bens de consumo duráveis e de capital (ver Gráfico 9). 
GRÁFICO 8 - VALOR, PREÇO E QUANTUM DAS EXPORTAÇÕES POR CLASSE DE PRODUTO VARIAÇÃO ACUMULADA NO ANO (\%)

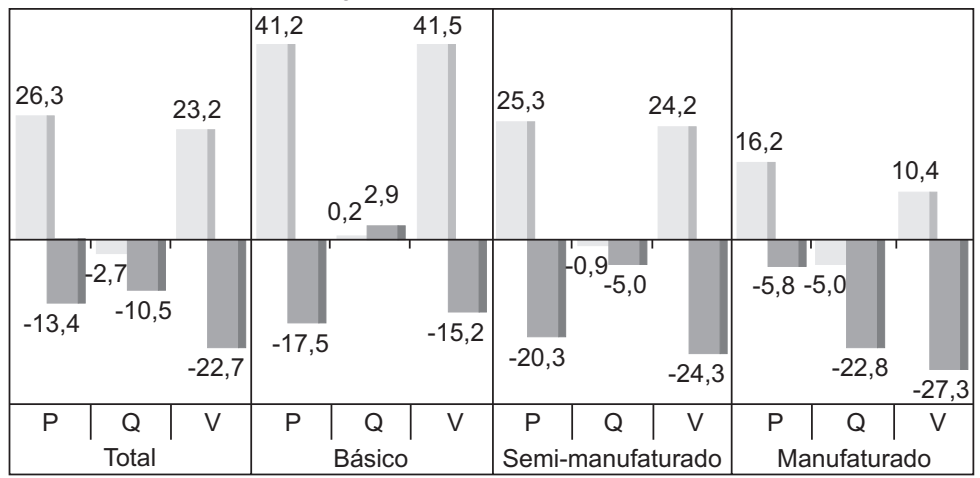

$\square 2008 \quad \square 2009$

Fonte: Funcex. Elaboração própria.

Nota: $\mathrm{P}=$ Preços; $\mathrm{Q}=$ Quantum; $\mathrm{V}=$ Valor.

GRÁFICO 9 - VALOR, PREÇO E QUANTUM DAS IMPORTAÇÕES POR CATEGORIA DE USO VARIAÇÃO ACUMULADA NO ANO (\%)

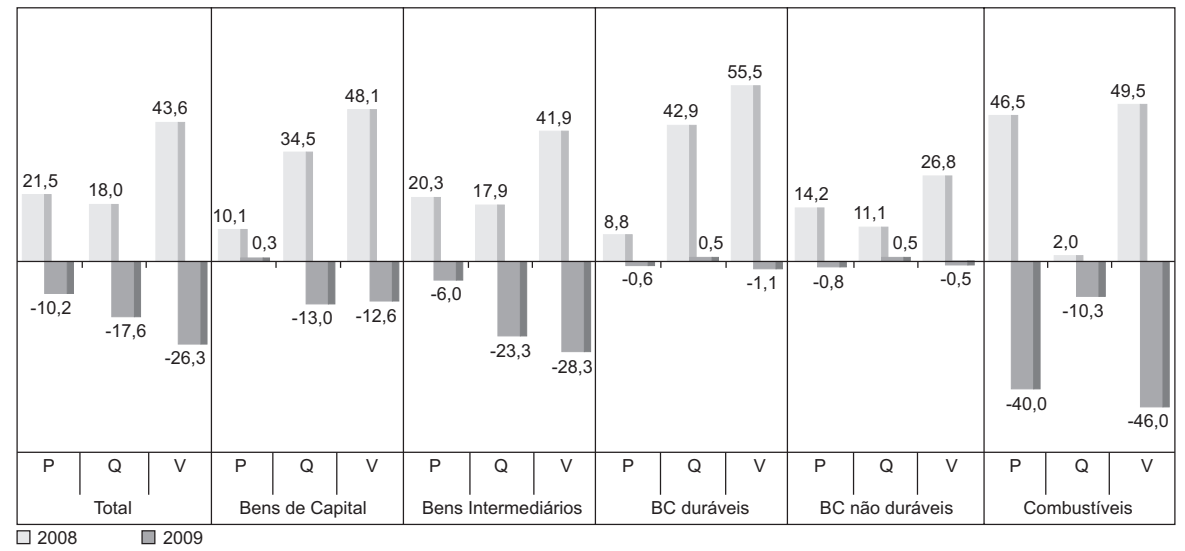

Fonte: Funcex. Elaboração própria.

Nota: $\mathrm{P}=$ Preços; $\mathrm{Q}=$ Quantum; $\mathrm{V}=$ Valor.

A deterioração do resultado comercial em 2008 decorreu, sobretudo, do contexto de apreciação cambial e maior dinamismo econômico que vigorou nos primeiros oito meses do ano. Esse contexto resultou em um aumento expressivo das importações de bens e insumos de maior conteúdo tecnológico em resposta às decisões de consumo, produção e investimento (ver Gráfico 6) e, consequentemente, do aumento da contribuição negativa desses produtos ao saldo comercial, sobretudo daqueles de média intensidade tecnológica (Gráficos 10 e 11). 
GRÁFICO 10 - SALDO COMERCIAL POR CONTEÚDO TECNOLÓGICO (US\$ BILHÕES)

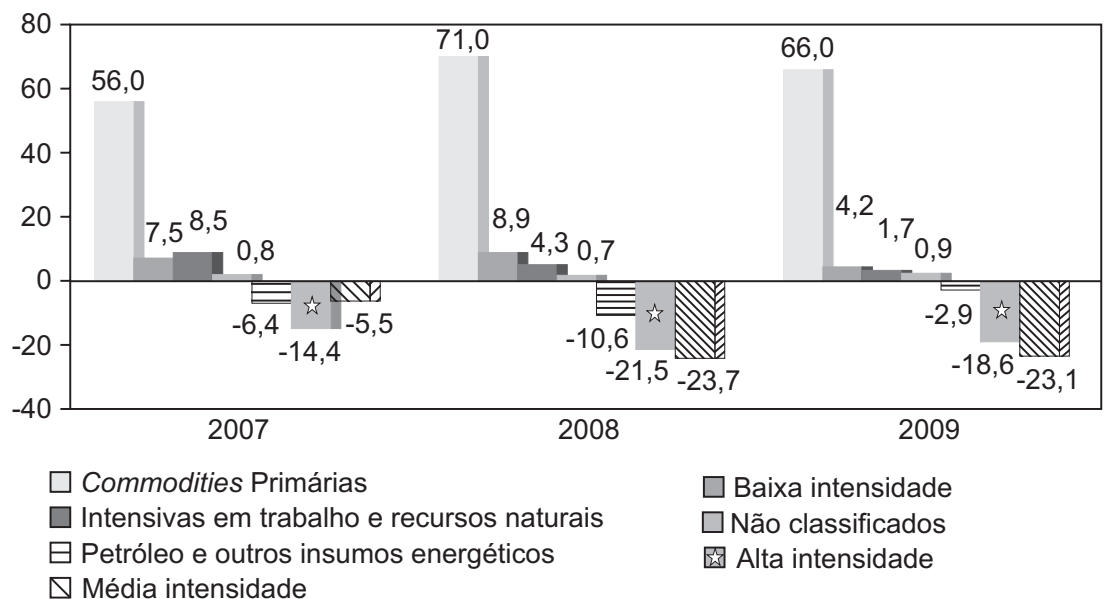

Fonte: MDIC. Elaboração própria.

Assim, pode-se afirmar que o perfil da pauta exportadora (concentrada em commodities) e importadora brasileiras (com maior participação de bens manufaturados de maior conteúdo tecnológico, cuja demanda tem uma elevada elasticidade-renda) contribuiu, em 2008, para atenuar o impacto negativo da crise sobre o comércio exterior. A alta anual dos preços das commodities em 2008 garantiu a sustentação de uma taxa ainda razoável de crescimento das exportações e explica o aumento da participação desse grupo no total das vendas externas (de 41,1\% em 2007 para 44,2\% em 2008). Essa mesma conclusão aplica-se ao desempenho do comércio exterior em 2009. Nesse ano, enquanto o perfil da pauta exportadora contribuiu para atenuar o recuo das vendas externas em um contexto internacional adverso, a concentração das importações em bens intermediários e de consumo durável, de maior valor agregado, acentuou o impacto da forte retração da atividade econômica interna no último trimestre de 2008 e primeiro de 2009 sobre a demanda por produtos importados.

No que diz respeito às exportações, os preços das commodities retomaram um movimento de alta a partir de janeiro, que se sustentou (ou se acelerou) até o final de 2009 e foi bastante generalizado entre as diversas categorias, abrangendo produtos com elevada participação na pauta exportadora brasileira (como grãos de soja e metais). Embora em dezembro as cotações permaneciam em patamares inferiores aos registrados em julho de 2008, esse movimento contrasta com a experiência passada, já que ocorreu em um estágio inicial da recuperação da produção industrial global. Nas recessões anteriores, os preços seguiam em queda nesse estágio ou cresciam em um ritmo bem inferior ao observado em 2009 (IMF, 2009). 

GRÁFICO 11 - COMPOSIÇÃO DAS EXPORTAÇõES E IMPORTAÇõES POR CONTEÚDO
TECNOLÓGICO (\%)

\begin{tabular}{|c|c|c|c|}
\hline $7,6 \%$ & $7,8 \%$ & \multirow[b]{2}{*}{$20,9 \%$} & \multirow[b]{2}{*}{$23,7 \%$} \\
\hline $8,5 \%$ & $6,6 \%$ & & \\
\hline $6,6 \%$ & $6,1 \%$ & \multirow{2}{*}{$\begin{array}{r}4,4 \% \\
4,9 \%\end{array}$} & $4,5 \%$ \\
\hline $9,7 \%$ & $9,1 \%$ & & $5,9 \%$ \\
\hline $22(1)$ & 1860 & $16,9 \%$ & $13,0 \%$ \\
\hline $44,2 \%$ & $50,3 \%$ & & \\
\hline \multirow{2}{*}{ Exportações } & & & \\
\hline & Importaçoes & Exportaçoes & Importaçoes \\
\hline
\end{tabular}

$\square$ Commodities primárias $\quad \square$ Petróleo e outros insumos enérgicos

$\mathbb{Q}$ Média intensidade

$\square$ Intensivas em trabalho e recursos naturais

Baixa intensidade

$\square$ Alta intensidade

Não classificados

Fonte: MDIC. Elaboração própria.

Três fatores foram responsáveis por essa trajetória atípica, ao lado do maior peso das economias "emergentes" no produto mundial - que assumiram a dianteira na recuperação e cuja elasticidade-renda da demanda por commodities é mais elevada do que nos países avançados. Em um primeiro momento, além do aumento da demanda da China (que aproveitou os preços deprimidos para recompor estoques), os investimentos especulativos nos mercados de commodities e a formação de estoques (estimulados pelo excesso de liquidez e pelas baixas taxas de juros nos países avançados) e a desvalorização do dólar. Em um segundo momento, o crescente consenso de que a recuperação global teria início ainda em 2009 fomentou a demanda por commodities, sustentou aqueles investimentos e o acúmulo de estoques (IMF, 2009 e 2010).

\section{CONSIDERAÇõES FINAIS E IMPLICAÇÕES DE POLÍTICA ECONÔMICA}

Ao longo deste artigo evidenciou-se que, tanto do ponto de vista financeiro quanto comercial, o quadro internacional de instabilidade financeira e retração real se transmitiu com elevada intensidade no BOP do país, o que reforça a percepção de que o Brasil não ficou imune à crise. Procurou-se argumentar que o desempenho do setor externo da economia nacional tem sido fortemente condicionado pelos ciclos financeiros externos e pelas flutuações nos preços das commodities.

Ademais, o perfil de inserção externa de uma economia é condicionado pelo regime macroeconômico vigente e pelas suas características estruturais, tais como os graus de abertura e de internacionalização financeiras e as características da estrutura produtiva. No período recente a economia brasileira passou por uma importante transformação que ampliou seu grau de abertura financeira, com a recomposição na 
estrutura dos passivos externos, manutenção de uma menor participação relativa de setores intensivos em tecnologia no superávit comercial e, por decorrência, maior importância de setores processadores de recursos naturais. Tais características ajudaram a melhoria nas condições de financiamento externas, nos anos que se antecederam à crise. A recuperação recente também vem sendo marcada pela elevada demanda de ativos emitidos no Brasil, bem como pela recomposição na demanda por matérias-primas em economias emergentes mais dinâmicas, particularmente a China.

Tais preocupações têm sido ressaltadas em outros trabalhos, tais como Michel e Carvalho (2009), Bacha e Goldfajn (2009), Giambiagi e Barro (2009), Velloso (2009) e Bresser-Pereira (2010). Todavia, há divergências de posicionamento no que se refere às implicações normativas do padrão de inserção externa da economia brasileira, antes e depois da crise financeira global. Em uma perspectiva mais liberal, a ênfase recai sobre reformas institucionais, microeconômicas e macroeconômicas - especialmente nos campo trabalhista, tributário e previdenciário - tidas como necessárias de aumentar a poupança doméstica e a eficiência geral da economia. Assume-se a manutenção do tripé de gestão macroeconômica - câmbio flutuante, superávits fiscais e metas de inflação - e do grau atual de abertura financeira. Ainda neste campo, questões como a desindustrialização e "commoditização" não se colocam como problemas a serem enfrentados por políticas governamentais (BACHA e GOLDFAJN, 2009; GIAMBIAGI e BARRO, 2009; VELLOSO, 2009). Sem desconsiderar as preocupações com o aumento da competitividade nos seus diversos níveis, posições mais críticas apontam para a necessidade de políticas desenvolvimentistas que garantam a manutenção da diversificação da estrutura produtiva industrial. Controles sobre os fluxos de capitais e readequação da relação câmbio-juros seriam peças centrais da estratégia alternativa (VELLOSO, 2009; BRESSER-PEREIRA, 2010a e 2010b; IEDI, 2011; CASTILHO, 2011).

Para situar nosso posicionamento, nestas considerações finais são acrescentadas duas informações adicionais que, em conjunto com a análise das seções anteriores, permitem a construção de proposições de política econômica que visem à minimização de riscos potenciais para o período pós-crise. Em primeiro lugar, é importante estabelecer uma relação entre o desempenho exportador e a situação de solvência externa da economia brasileira. O indicador fundamental na análise da situação de solvência externa de um país - que reflete a vulnerabilidade externa de médio e longo prazo - consiste na razão entre o Passivo Externo Líquido (PEL) e as exportações, a fonte de geração autônoma de divisas, necessárias para amortizar esse passivo. $\mathrm{O}$ aumento deste indicador indica deterioração desta situação e viceversa (ver Tabela 4). 
TABELA 4 - Passivo externo e indicador de solvência externa

\begin{tabular}{|c|c|c|c|c|c|c|c|}
\hline & \multirow{2}{*}{ PEL ${ }^{(1)}$} & \multicolumn{3}{|c|}{$\begin{array}{l}\text { Principais componentes } \\
\text { do Passivo externo }\end{array}$} & \multirow{2}{*}{$\begin{array}{l}\text { D. reservas } \\
\text { cambiais }\end{array}$} & \multirow{2}{*}{$\begin{array}{l}\text { PEL/export. } \\
\text { acumul.12 } \\
\text { meses }^{(2)}\end{array}$} & \multirow{2}{*}{$\begin{array}{l}\text { Mema export. } \\
\text { acumul. } 12 \text { meses } \\
\text { (US\$ milhões) }\end{array}$} \\
\hline & & $\begin{array}{l}\text { A. invest. } \\
\text { direto líq. }\end{array}$ & $\begin{array}{l}\text { B. invest. } \\
\text { porfolio líq. }\end{array}$ & $\begin{array}{l}\text { C. outros } \\
\text { invest. líq. }\end{array}$ & & & \\
\hline dez./05 & 331.085 & 116.302 & 221.793 & 46.689 & 53.799 & 2,79 & 118.529 \\
\hline dez./06 & 368.812 & 106.696 & 289.154 & 58.470 & 85.839 & 2,68 & 137.807 \\
\hline dez./07 & 550.408 & 173.565 & 486.471 & 69.077 & 180.334 & 3,43 & 160.649 \\
\hline dez./08 & 278.798 & 125.478 & 266.226 & 78.272 & 193.783 & 1,41 & 197.942 \\
\hline dez./09 & 596.743 & 400.808 & 561.848 & 113.810 & 238.520 & 3,90 & 152.995 \\
\hline
\end{tabular}

Notas: (1) O BCB não fornece os dados do Passivo externo líquido (PEL). Para obtê-lo, foram utilizados os dados da Posição internacional de investimento (Ativo e Passivo). (2) Essa razão constitui o principal indicador de solvência externa de uma economia. Fonte: Banco Central do Brasil, Nota para Imprensa Setor Externo (Quadros 58 e 58A). Elaboração própria.

Entre 2005 e 2006, o forte crescimento das exportações foi fundamental para evitar a alta deste indicador, associada ao crescimento do passivo externo líquido (resultado, por sua vez, dos fluxos de capitais absorvidos no período); já em 2007 isso não ocorreu, pois o boom de fluxos de capitais não foi acompanhado pela manutenção do dinamismo das exportações, que já sentiam os efeitos adversos do câmbio apreciado; em 2008, a queda do indicador reflete, principalmente, a queda do passivo externo provocada pela saída de recursos externos e pela desvalorização do real. Em 2009, em contrapartida, o retorno dos fluxos de capitais e a apreciação do real - na esteira da redução progressiva da aversão dos riscos dos investidores globais - resultou na expressiva ampliação deste passivo em um contexto de retração das exportações (associada a esta apreciação, bem como a demanda externa reprimida), que teve como consequência a deterioração do indicador de solvência externa (ver Tabela 4).

Em segundo lugar, há que se enfatizar a questão da heterogeneidade do perfil tecnológico da pauta exportadora brasileira para os 15 principais parceiros comerciais do país (Gráficos 12 e 13). Em 2009, a China assumiu a primeira posição, desbancando os Estados Unidos e a Argentina (primeiro e segundo colocados em 2008), que passaram para o segundo e terceiro lugares. Vale mencionar que esta "dança de cadeiras" nas primeiras posições talvez seja conjuntural, já que está associada aos efeitos da crise econômica mundial (retração do PIB e das importações nesses dois países, aceleração do crescimento da China e alta dos preços das commodities ao longo de 2009).

Como mostra o Gráfico 13, o perfil da pauta exportadora é mais favorável no caso dos parceiros latino-americanos, com destaque para a Argentina e o México (que ocupavam a $3^{\mathrm{a}}$ e $14^{\mathrm{a}}$ em 2009 - ver Gráfico 12), o que era de se esperar já que essas economias absorvem, principalmente, bens de maior valo agregado. Nestes dois últimos países, a participação relativa da categoria de "média intensidade tecnológica" em 2009 foi de, respectivamente, 52\% e 64\% (a mais elevada), em função, sobretudo, das exportações do complexo automobilístico, estimuladas pelos acordos comerciais. Se somarmos as participações das duas categorias de maior conteúdo tecnológico, o México permanece na liderança (77\%), seguido pela Argentina (66\%), Chile (54\%) e Venezuela (44\%). Já 
se considerarmos somente a categoria de alta intensidade, o Chile tem a maior participação relativa (14\%), seguido pela Argentina e França (14\%), México (13\%) e Estados Unidos, Alemanha e Venezuela (11\%). No caso dos Estados Unidos, a perda de participação da categoria de alta intensidade tecnológica nos últimos anos é especialmente preocupante, dada a dimensão e o dinamismo do mercado americano.

\section{GRÁFICO 12 - PARTICIPAÇÃO DOS PRINCIPAIS PARCEIROS COMERCIAIS NAS EXPORTAÇÕES BRASILEIRAS, 2008-2009}

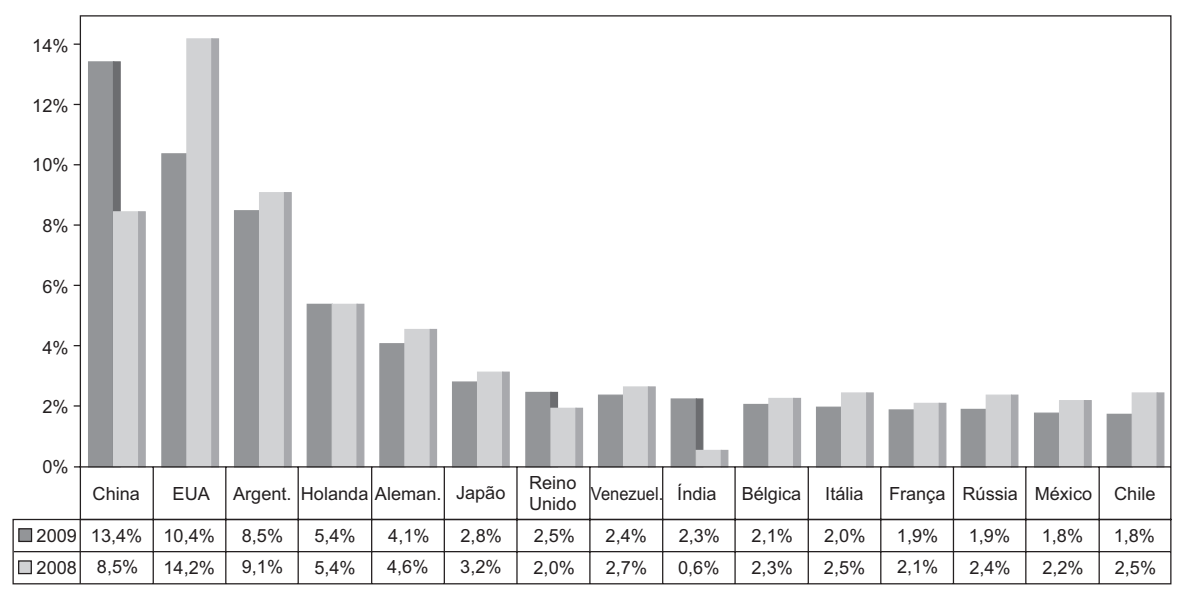

Fonte: MDIC. Elaboração própria.

GRÁFICO 13 - COMPOSIÇÃO DAS EXPORTAÇÕES POR CONTEÚDO TECNOLÓGICO EM 2009 (\%)

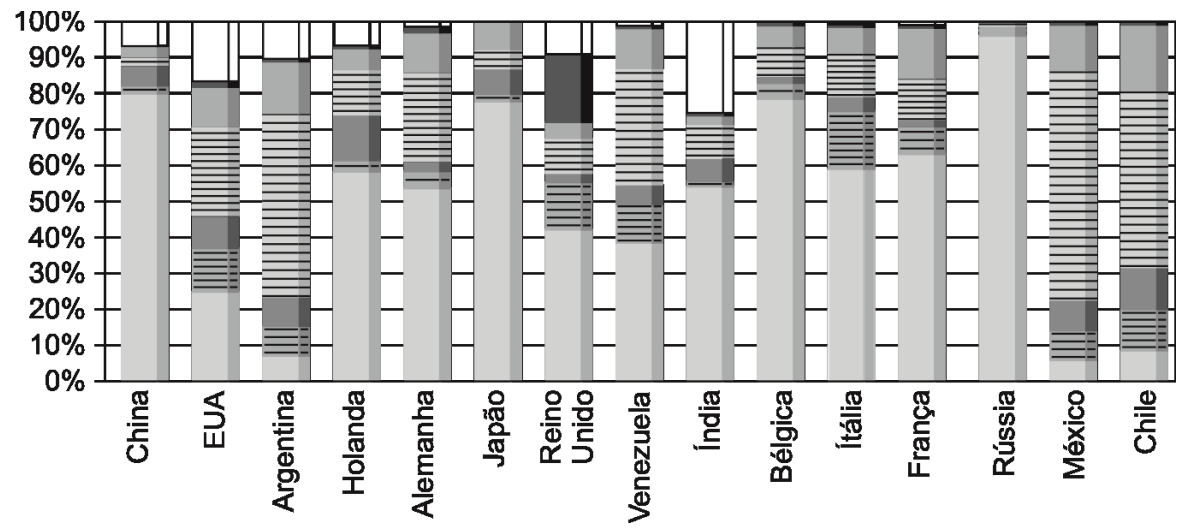

$\square$ Commodities primárias

$\square$ Baixa intensidade

$\square$ Não classificados

Fonte: MDIC. Elaboração própria. $\boxminus$ Intensivas em trabalho e recursos naturais

$\boxminus$ Média intensidade $\square$ Alta intensidade

$\square$ Petróleo e outros insumos energéticos 
Nos demais países, destaca-se a elevada participação das commodities primárias. Em relação aos países europeus, historicamente nossa pauta exportadora foi concentrada nesses bens, de baixa elasticidade-renda da demanda e sujeitos a barreiras comerciais. Somente Reino Unido e Alemanha apresentam uma pauta mais diversificada, com uma maior participação da categoria de média intensidade tecnológica (no caso deste último país, relacionada com o comércio intra-firma do setor automobilístico).

No caso da China, a concentração da nossa pauta exportadora em commodities está associada ao perfil do seu crescimento, liderado por setores intensivos em commodities metálicas e industriais - automotivo, metalúrgico e de construção civil -, que pressionou a demanda por esses bens, ao mesmo tempo em que o crescimento populacional fomentou a compra externa de alimentos e demais commodities agrícolas. Assim, o aumento da sua importância como destino das nossas vendas externas nos últimos anos ancorou-se na ocupação de espaços não-aproveitados até então por setores competitivos, que podem se saturar nos próximos anos. Considerando que as commodities primárias responderam por $50 \%$ das exportações brasileiras em 2009, enquanto que as importações chinesas vêm se concentrando em produtos de maior conteúdo tecnológico, a continuidade da expansão destas vendas dependerá da diversificação das nossas exportações. Ademais, o próprio processo de desenvolvimento resultará, em algum momento no futuro, em uma menor absorção de commodities pela China, seja devido ao seu impacto sobre a elasticidade-renda da demanda interna por esses bens, seja em função dos limites de expansão da capacidade instalada nos setores industriais intensivos em commodities metálicas.

Após essas considerações, é possível apresentar algumas recomendações de política voltadas para a melhora do desempenho exportador brasileiro, que envolvem ações na área macroeconômica, comercial e financeira. Em âmbito macroeconômico, como mostrou a evolução do indicador de solvência externa, a sustentação de taxas elevadas de crescimento das exportações é fundamental para garantir a estabilidade e/ou a melhora da situação de vulnerabilidade externa da economia brasileira, que tem um alto grau de integração financeira e produtiva com o exterior e, com isso, um passivo externo estruturalmente elevado. Para tanto, é necessário um regime distinto do atual, que priorize a manutenção da taxa de câmbio em um patamar competitivo. A combinação de políticas cambial e monetária vigente no período analisado pecou pela imprudência ao deixar o real se apreciar numa intensidade inédita, o que pode comprometer a capacidade de geração de divisas nos próximos anos.

A apreciação cambial esteve diretamente associada à política monetária excessivamente restritiva, bem como à ampliação do grau de abertura financeira. Nesse contexto, a política de acumulação mais agressiva de reservas cambiais - praticada por outros países emergentes que adotam regimes de câmbio flutuante -, além de 
envolver custos mais elevados devido ao elevado diferencial entre os juros internos e externos, revelou-se insuficiente para conter a volatilidade da taxa de câmbio e mantê-la em um patamar competitivo. Assim, é possível mencionar duas alternativas de política, não excludentes, a essa armadilha da política cambial (além da redução mais rápida e intensa da taxa de juros básica, que persiste em um patamar elevado em relação aos demais países emergentes):

i) a redução do grau de abertura financeira mediante a imposição de controles de capitais sobre os investimentos de portfólio em ações e títulos de renda fixa e sobre as operações dos investidores estrangeiros com derivativos cambiais em situações de excesso de fluxos de capitais especulativos. Esses controles podem se revelar instrumentos coadjuvantes na gestão do regime de câmbio flutuante, funcionando como "filtros" que atenuam os efeitos instabilizadores dos fluxos de capitais de curto prazo (como ilustram as experiências de alguns países emergentes no contexto recente);

ii) uma estratégia de política cambial que tenha como meta o patamar de taxa de câmbio e, assim, como objetivo a manutenção da competitividade das exportações. Na fase de auge do ciclo de liquidez internacional, as intervenções do BCB na ponta compradora do mercado de câmbio visaram reconstituir um colchão de liquidez em moeda estrangeira e reduzir a volatilidade cambial, sem procurar influenciar a tendência de apreciação do real (que se revelou fundamental para a eficácia da política de metas de inflação).

Nesse contexto, o patamar da taxa de câmbio não constituiu uma meta da gestão cambial. A autoridade brasileira somente interveio, em algumas circunstâncias, para reduzir o ritmo desta apreciação, já que mudanças abruptas desse patamar podem estimular movimentos especulativos e aumentar a volatilidade cambial. O BCB perseguiu uma estratégia, previamente anunciada aos seus dealers, de atuar no final do dia, antes do fechamento do mercado, absorvendo as "sobras" de dólares aos preços vigentes no momento, sem procurar influenciar as cotações (estratégia recomendada quando a autoridade monetária não pretende influenciar o patamar de taxa de câmbio).

No que diz respeito à política comercial, a análise do perfil da pauta exportadora para os principais parceiros reafirmou a importância das relações comerciais com os países latino-americanos, que importam, sobretudo, bens de maior valor agregado e conteúdo tecnológico. Assim, o governo brasileiro deveria investir nessas relações, já que mudanças na composição das nossas vendas externas para os demais parceiros no curto prazo são pouco prováveis, em função seja da maturidade (caso dos países europeus e dos Estados Unidos), seja do perfil das respectivas estruturas produtivas (caso da China). As ações podem envolver acordos comerciais e políticas de promoção de exportações, a abertura de novos mercados, o aumento da inserção das 
empresas de pequeno e médio porte na região e a ampliação da presença de produtos de maior valor agregado na pauta exportadora para a região.

Finalmente, é importante destacar que ainda existe espaço para o aperfeiçoamento do sistema público de crédito à exportação, que busca cumprir funções não desempenhadas pelo setor privado como, por exemplo, fornecer financiamentos com custos mais baixos e prazos mais longos, de forma a garantir às empresas domésticas condições de igualdade frente aos competidores estrangeiros, prover garantias contra os riscos (político, comercial etc.) inerentes à atividade exportadora, dar acesso a crédito às empresas de menor porte e priorizar os setores mais importantes de acordo com as orientações da política econômica. Nessa área, a nova instituição de fomento derivada do BNDES/Exim poderia começar a atuar na oferta de garantias e seguros contra riscos políticos e comerciais dos importadores, tipo de operação que a tornaria uma agência de crédito à exportação semelhante às suas congêneres estrangeiras.

\section{REFERÊNCIAS}

BACHA, E.; GOLDFAJN, I. (Org.) Como Reagir à Crise: políticas econômicas para o Brasil. São Paulo: Imago, 2009.

BRESSER-PEREIRA, L. C. (Org.). A Crise Global e o Brasil. São Paulo: Editora FGV, 2010a. . Doença holandesa e indústria. Rio de Janeiro: Editora FGV, 2010b.

CASTILHO, M. Impactos da crise econômica internacional sobre o comércio exterior brasileiro. In: ACIOLI, L. \& LEÃO, R. P. F. Crise financeira global: mudanças estruturais e impactos sobre os emergentes e o Brasil. Brasília: IPEA, 2011, p. 97-127 (no prelo).

CEPAL. Panorama de la inserción internacional de la América Latina y el Caribe 2007, tendencias 2008. oct.

EICHENGREEN, B. From Great Depression to Great Credit Crisis: similarities, differences and lessons. Presented at the 50th Economic Policy Panel Meeting, held in Tilburg on oct. p. 23-24, 2009.

FUNCEX. Boletim de comércio exterior, ano XIII, n. 1, jan., 2009.

FLIGENSPAN, F. Houve um processo de substituição de importações na indústria brasileira no período pós-desvalorizações cambial? Economia e Sociedade. Campinas, v. 14, n. 1, p. 109-131, jan./jun., 2005.

GIAMBIAGI, F.; BARROS, O. (Orgs.) Brasil Pós-Crise: agenda para a próxima década. São Paulo: Campus, 2009.

HOLLAND, M.; XAVIER, C. L. Dinâmica e competitividade setorial das exportações brasileiras: uma análise de painel para o período recente. Economia e Sociedade, v. 14, n. 1, p. 85-108, 2005. 
IEDI. A indústria de transformação por intensidade tecnológica: o desafio de crescer sem deteriorar ainda mais o saldo comercial. Carta IEDI. São Paulo: IEDI, n. 454, 11 de fev., 2011.

IIF - Institute of International Finance. Capital Flows to Emerging Market Economies, jan., 2010.

IMF - International Monetary Fund. Economic Outlook, abr., 2010.

World Economic Outlook, out., 2009.

World Economic Outlook, out., 2008.

KAPLINSKY, R. Revisiting the revisited terms of trade: will china make a difference, Institute of Development Studies, mar., 2005.

KREGEL, J. Financial Flows and International Imbalances: the role of catching up by late-industrializing developing countries, February - Working Paper n. 528. New York: Levy Economics Institute of Bard College, 2008.

MICHEL, R.; CARVALHO, L. (Orgs.). Crescimento econômico: setor externo e inflação. Brasília, DF: IPEA, 2009.

MOHANTY, M.S.; SCATIGNA, M. Has globalisation reduced monetary policy independence? In: BIS. Globalisation and monetary policy in emerging markets, BIS Papers n. 23, mai., 2005. Basle: Bank of International Settlement, 2005.

NEGRI, F. Padrões tecnológicos e de comércio exterior das firmas brasileiras. In: IPEA. Inovações, padrões tecnológicos e desempenho das firmas industriais brasileiras. Brasília: IPEA, 2005.

OREIRO, J. L.; FEIJÓ, C. Desindustrialização: conceituação, causas, efeitos e o caso brasileiro. Revista de Economia Política. São Paulo, v. 30, n. 2 (118), p. 219-232, abr./jun., 2010.

REINHART, C. M.; ROGOFF, K. S. This Time is Different: a Panoramic View of Eight Centuries of Financial Crises, March - NBER Working Paper n. 13.882, 2008.

ROSALES, O. Espacios de convergencia y de cooperación regional, LC/L.3201, Feb. Santiago, Chile: CEPAL, 2010.

SARTI, F.; SABATINI, R. Conteúdo tecnológico do comércio exterior brasileiros. Campinas: Unicamp. Instituto de Economia, 2003.

UNCTAD. Trade and Development Report. Geneve: United Nations Conference on Trade and Development, 2008.

World Investment Report. Geneve: United Nations for Trade and Development (2008 e 2009).

VELLOSO, J. P. R. (Coord.). Na crise, esperança e oportunidade, desenvolvimento como sonho brasileiro. Rio de Janeiro: Campus, 2009.

WORLD BANK. Swimming against the tide: how developing countries are coping with the global crises. Washington, D.C.: World Bank, 2009. 